\title{
Labour Relations at Manufactures in the Eighteenth Century: The Calico Printers in Europe*
}

\author{
CHRISTIAN SIMON
}

\section{INTRODUCTION}

Many studies on proto-industrialization have followed Franklin Mendels' work, and virtually all concern cottage industries in rural areas. Occasionally, authors are also interested in urban proto-industries, which are correctly considered home industries here. This production method (aside from traditional manual labour) has certainly been decisive, both in supplying expanding markets during the seventeenth and eighteenth centuries and in raising capital for commercial production of goods. Cottage industries were the prevailing form of industry at the start of the Industrial Revolution (and during the preceding. periods) and were consequently a direct prerequisite for it. ${ }^{1}$

This article, however, examines the manufacturing industry, a different method of production and one that has been somewhat neglected by research of the past few decades, since recent guides deem this industry economically insignificant: "The manufacturing industry remains in the minority."2 Although this attitude has affected research on women's

* Research for this article has been supported by the Fonds National Suisse de la Recherche Scientifique, Berne.

${ }^{1}$ Maxine Berg, The Age of Manufactures: Industry, Innovations and Work in Britain 1700 1820 (Oxford, 1985); idem (ed.), Markets and Manufacture in Early Industrial Europe (London, 1991); Karl Ditt and Sidney Pollard (eds), Von der Heimarbeit in die Fabrik: Industrialisiertung und Arbeiterschaft in Leinen- und Baumwollregionen Westeuropas während des 18. und 19. Jahrhunderss (Paderborn, 1992); Wilfried Reininghaus, Gewerbe in der fruhen Neuzeit (Munich, 1990), pp. 81-91; Sidney Pollard, Peaceful Conquest: The Industrialization of Europe 1760-1970 (Oxford, 1981); Franklin F. Mendels, "The First Phase of the Industrialization Process", Journal of Economic History, 32 (1972), pp. 241261; idem, "Des industries rurales a la proto-industrialisation: Historique d'un changement de perspective", Annales E.S.C., 39 (1984), pp. 977-1008; Peter Kriedte, Hans Medick and Jürgen Schlumbohm, Industrialisierung vor der Industrialisierung: Gewerbliche Warenproduktion auf dem Land in der Formationsperiode des Kapitalismus (Göttingen, 1977); L. A. Clarkson, Proto-Industrialization: The First Phase of Industrialization (London, 1985).

2 "L'industrie manufacturière reste tout a fait minoritaire". Fernand Braudel, Civilisation matérielle, économie et capitalisme 15e-18e siècle. Vol. II, Les jeux de l'échange (Paris, 1979), p. 290; Paul Mantoux, The Industrial Revolution in the 18th Century, ed. T. S. Ashton (London, 1961), p. 89. Germany around 1800: in the traditional trades worked 1.3 million people, in putting-out systems or cottage industries 1.0 million, in manufactures 0.1 million; total population of Germany was about 23 million, see Karl Heinrich Kaufhold, "Das deutsche Gewerbe am Ende des 18. Jahrhunderts, Handwerk, Verlag und Manufak- 
work with few exceptions, too, the manufactures were the ones to gather large groups of women under one roof, thus providing a fairly solid basis for studying the difficulties of women. ${ }^{3}$ While manufactures employed fewer individuals in Europe than cottage industries and putting-out systems, justice demands consideration of the "working conditions" in the manufactures. As the various types of production should be seen as interrelated, viewing proto-industrialization exclusively in terms of cottage industries would be too restrictive.

There have been several worthwhile attempts to define manufactures. ${ }^{4}$ The distinction between traditional trades (Handwerk, a smaller type of business, which - as assumed by much earlier research - usually served the market for individual orders in the vicinity, and in Europe was primarily viewed by German authors as pertaining to the guild system), versus cottage industries (which often had no affiliation to guilds, like the manufactures, although production was decentralized) and the putting-out. system (Verlag) is crucial. Division of labour is an important aspect of this description of manufactures. Unfortunately, these definitions all contain some ambiguity, particularly as they are often based on inaccurate assumptions. Handwerk does not necessarily involve a guild, nor does it always serve a local market, or produce finished

tur", in Helmut Berding and Hans-Peter Ullmann (eds), Deutschland zwischen Revolution und Restauration (Königstein, 1981), pp. 311-327.

${ }^{3}$ Heide Wunder, "Zur Stellung der Frau im Arbeitsleben und in der Gesellschaft des 15.-18. Jahrhunderts: Eine Skizze", Geschichtsdidaktik, 6 (1981), pp. 239-250: "While manufactures [...] did employ women, women's economic significance as well as their share of work in the labour market were minimal", p. 246; Rita Bake, Vorindustrielle Frauenerwerbsarbeit: Arbeits-und Lebensweise von Manufakturarbeiterinnen im Deutschland des 18. Jahrhunderts unter besonderer Berucksichtigung Hamburgs (Cologne, 1984).

4 Compare Karl Heinrich Kaufhold, Das Gewerbe in Preußen um 1800 (Göttingen, 1978); idem, "Das deutsche Gewerbe am Ende des 18. Jahrhunderts, Handwerk, Verlag und Manufaktur", in Berding and Ullmann, Deutschland zwischen Revolution und Restauration, pp. 311-327; Braudel, Civilisation materielle, vol. II, p. 287; Wilfried Reininghaus, Gewerbe in der frihen Neuzeit (Munich, 1990), p. 4; Gerhard Slawinger, Die Manufaktur in Kurbayern (Munich, 1966), pp. xv-xvii; Herbert Hassinger, "Der Stand der Manufakturen in den deutschen Erblandern", in Friedrich Lutge (ed.), Die wirtschaftliche Situation in Deutschland und Osterreich um die Wende vom 18. zum 19. Jahrhundert: Bericht uber eine Arbeitstagung der Gesellschaft für Sozial- und Wirtschafisgeschichte (Stuttgart, 1964), pp. 110-176; Gustav Otruba (ed.), Osterreichische Fabriksprivilegien vom 16. bis ins 18. Jahrhundert (Vienna [etc.], 1981); Wolfram Fischer, Wirschaft und Gesellschaft im Zeitalter der Industrialisierung (Gottingen, 1972), p. 360; Georg Jahn, "Die Entstehung der Fabrik", Jahrbuch für Gesetzgebung, Verwaltung und Volkswirtschaft, 69 (1949), p. 111; Kriedte et al., Industrialisierung, pp. 225ff. For the use of the term "manufacture" by Karl Marx, see Maxine Berg, Age of Manufactures, p. 70; the terminology of the eighteenth century is discussed by Ulrich Troitzsch, "Manufakturen in Deutschland und ihre Behandlung in der kameralistischen Literatur: Ansătze zu einem Vergleich", Wirtschaftskrafte und Wirtschaftswege, 4 (1978), pp. 611-624. Although the word manufacture can indicate a kind of trade, I use it for a type of factory also called "manufactories", see, for example, William Otto Henderson, Manufactories in Germany (Frankfurt [etc.], 1985). 
products at the workshop for a specific customer. Finally, an officially independent master craftsman is often dependent upon an entrepreneur.

The major difference between the manufactures and the factories was that the manual skills of workers dominated the production process rather than machines, as with the latter. Since mechanization often turned manufactures into factories, they may be considered proto-factories. ${ }^{5}$

- We should not assume that all steps required for manufacturing an item took place within the manufacture. Rather, the manufacture frequently accounted for part of the production process in the same business, which might also include a cottage industry and even individual craftsmen. This situation may be called a "decentralized manufacture". Especially with the forms of heavy commercial production that prevailed during the eighteenth century, several types of organizations could be combined in one industry in one region. A business might combine rural cottage industry, itinerant manual labour from a guild and manufacturing into a corporation. Such a business is considered "polymorphous".6

This branch primarily included calico printing, which was especially likely to take place in large manufactures. Nevertheless, this industry also included small and very small companies that resembled artisans' workshops. ${ }^{7}$ Others have written about the economic history of large calico printing manufactures. Its economic significance for the development of capitalism in banking and industry has also been explored in depth. ${ }^{8}$ This article will focus on working conditions and labour relations

s Fritz Redlich, "The Industrial Development of Europe: Reality, Symbols, Images", Kyklos, 17 (1964), pp. 372-402; Stanley David Chapman, "The Textile Factory before Arkwright", Business History Review, 48 (1974), proposes distinguishing proto-factories from factories by the fact that proto-factories used only batch production, while factories ran flow production. Also see Herbert Matis, "Betriebsorganisation, Arbeitsverfassung und Struktur des Arbeitsmarktes in der Phase der Proto-Industrialisierung", in Franz Matis and Joseph Riedmann (eds), Exportgewerbe und Außenhandel vor der Industriellen Revolution (Innsbruck, 1984), p. 140.

- Günter Bayerl and Ulrich Troitzsch, "Die Antizipation der Industrie - der vorindustrielle Grossbetrieb, seine Technik und seine Arbeitsverhältnisse", in Claus Grimm (ed.), Auf. bruch ins Industriezeitalter. Vol. 1, Linien der Ennvicklungsgeschichte (Munich, 1985), pp. 87-106; Berg, Age of Manufactures, pp. 84ff.: "polymorphic nature of industrial Organization".

7 Small workshops could grow into larger manufactures, but they often coexisted with large proto-factories. For example, see Ramon Grau and Marina López, "Empresari i capitalista a la manufactura catalana del segle XVIII: Introduccio a l'estudi de les fábriques d'indianes", Recerques, 4 (1974), pp. 19-57. For Avignon, see Henti Chobaut, "L'industrie des indiennes à Avignon et à Orange 1677-1884", Mémoires de l'Académie de Vaucluse, IIIe série, 3 (1938), pp. 133-158.

Herbert Lüthy, La Banque protestante en France de la révocation de l'édit de Nantes a la Révolution. Vol. II, De la banque aux finances 1730-1794 (Paris, 1961), pp. 104, 663ff; Maurice Lévy-Leboyer, Les banques europénnes et l'industrialisation internationale dans la premiere moitie du XIXe siecle (Paris, 1964), pp. 41ff; Stanley David Chapman, "The Role of Calico Printing in the Eighteenth Century European Economy", in Ulrich Troitzsch 
at the manufactures. Calico printing was not usually part of the guild system or part of the trades (Handwerke) subject to regulation by the authorities. One consequence was that corporations of master craftsmen had no power over the organization of the business or those employed there. Conversely, guild members were often unable to work for manufactures, as regulations prohibited the combination of guild membership and employment at a manufacture. ${ }^{9}$

\section{PRODUCTION ORGANIZATION AT CALICO PRINTING MANUFACTURES (Figure 1): TECHNOLOGY AND STAFF}

Calico printing manufactures combined several operations (see Figure 2). ${ }^{10}$ The most important ones included:

(ed.), Technologischer Wandel im XVIII. Jahrhundert (Wolfenbüttel, 1981), pp. 53-71; Stanley David Chapman and Serge Chassagne, European Textile Printers in the Eighteenth Century: A Study of Peel and Oberkampf (London, 1981), pp. 3-21.

${ }^{9}$ For the German conception of Zunft in late eighteenth century see Wolfram Fischer, Wirtschaft und Gesellschaft im Zeitalter der Industrialisierung (Göttingen, 1972), pp. 296314. For the French jurande see William H. Sewell, Jr, Work and Revolution in France (Cambridge, 1980), p. 26. The organization of British trades is explained in I. J. Prothero, Artisans and Politics in Early Nineteenth Century London (London, 1979), pp. 22ff., and C. R. Dobson, Masters and Journeymen (London, 1980), pp. 151ff.

${ }^{10}$ The monographs on calico printing explain the operations and organization of work within a manufacture, e.g. Robert Forrer, Die Kunst des Zeugdrucks vom Mittelalter bis zur Empirezeit (Strasbourg, 1898); Jacques Waitzfelder, Der Augsburger Johann Heinrich von Schule: Ein Pionier der Textilwirtschaft im XVIII. Jahrhundert (Leipzig, 1929); Ruth Schillinger, Die wirtschaftliche Entwicklung des Stoffdrucks (Cologne, 1964); Alfons K. L. Thijs, "Schets van de ontwikkeling der katoendrukkerij te Antwerpen 1753-1813", Bijdragen tot de geschiedenis inzonderheid van het oud hertogdom Brabant, 3rd ser., 53 (1970), pp. 157-190; idem, Van "werkwinkel" tot "fabriek": De textielnijverheid te Antwerpen (Brussels, 1987); Florence M. Montgomery, Printed Textiles: English and American Cottons and Linens 1700-1850 (London, 1970) (contains a guide to the literature); John Irwin and Katharine B. Brett, Origins of Chintz (London, 1970); Catharina Lis and Hugo Soly, Een groot bedrijf in een kleine stad: De firma De Heyder \& Co., te Lier 17571834 (Lier, 1987); Josette Brédif, Toiles de Jouy (London, 1989); Henri-René d'Allemagne, La toile imprimée et les indiennes de traite (Paris, 1942); Musée de l'impression sur étoffes de Mulhouse = Bulletin Trimestriel de la Societe Industrielle de Mulhouse, 761, no. IV (1975); Geoffrey Turnbull, A History of the Calico Printing Industry of Great Britain (Altrincham, 1951); Sergio Aiolf, Calicos und gedrucktes Zeug (Stuttgart, 1987); Anne Jean-Richard, Kattundrucke der Schweiz im XVIII. Jahrhundert (Basel, 1968); Christian Simon, Wollt Ihr Euch der Sklaverei kein Ende machen? Der Streik der Basler Indiennearbeiter 1794 (Allschwil, 1983); Pierre Caspard, La Fabrique-Neuve de Cortaillod (Paris, 1979); Micheline Viseux, Le conton, l'impression (Thonon-les-Bains, 1991). The most important document on the history of calico printing manufactures is the manuscript by Jean Ryhiner, partially published in D. Dollfuss-Ausset, Materiaux pour la coloration des etoffes (Paris, 1865). A new, complete edition of this text is being prepared by Monique Drosson and the author. 


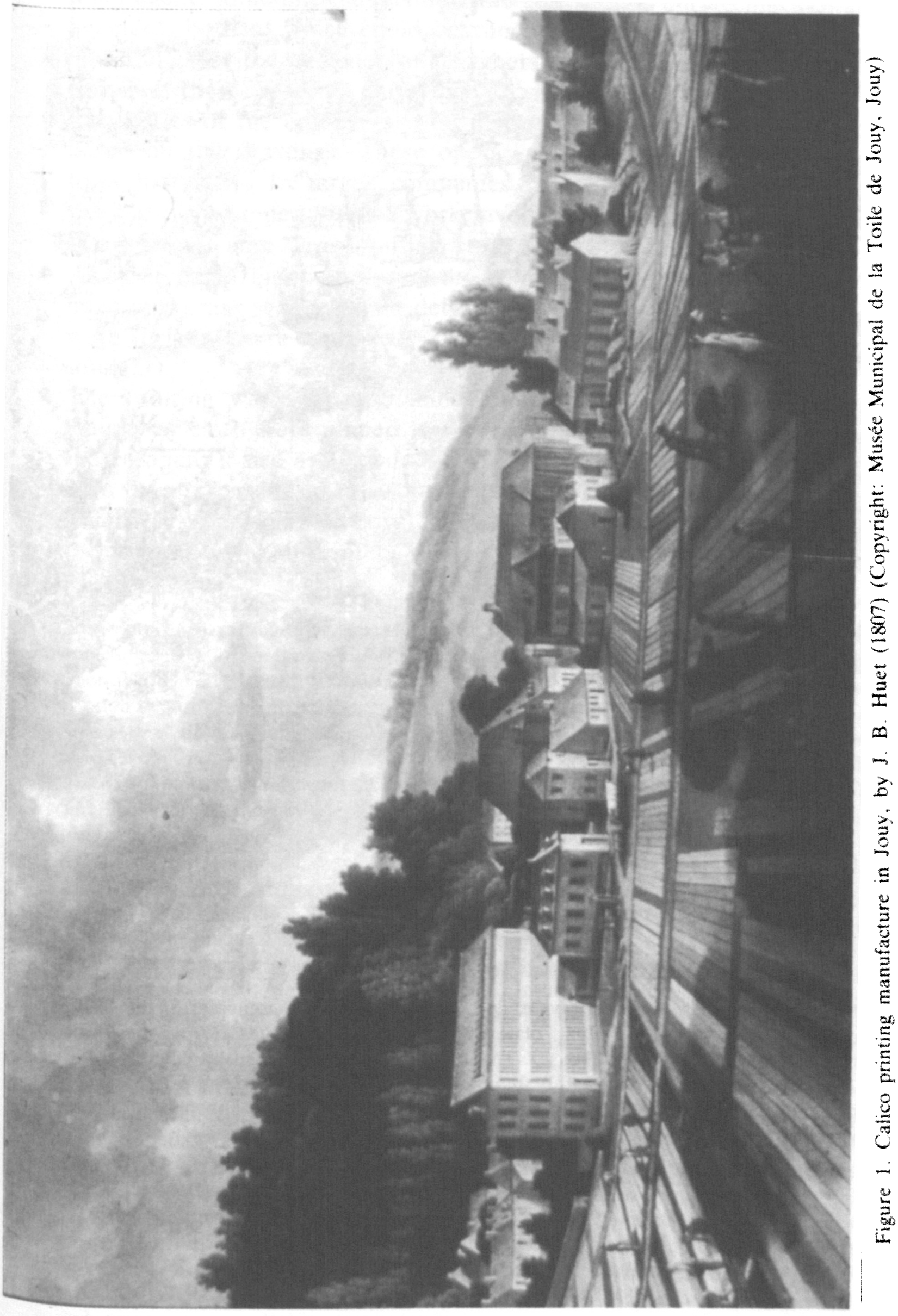




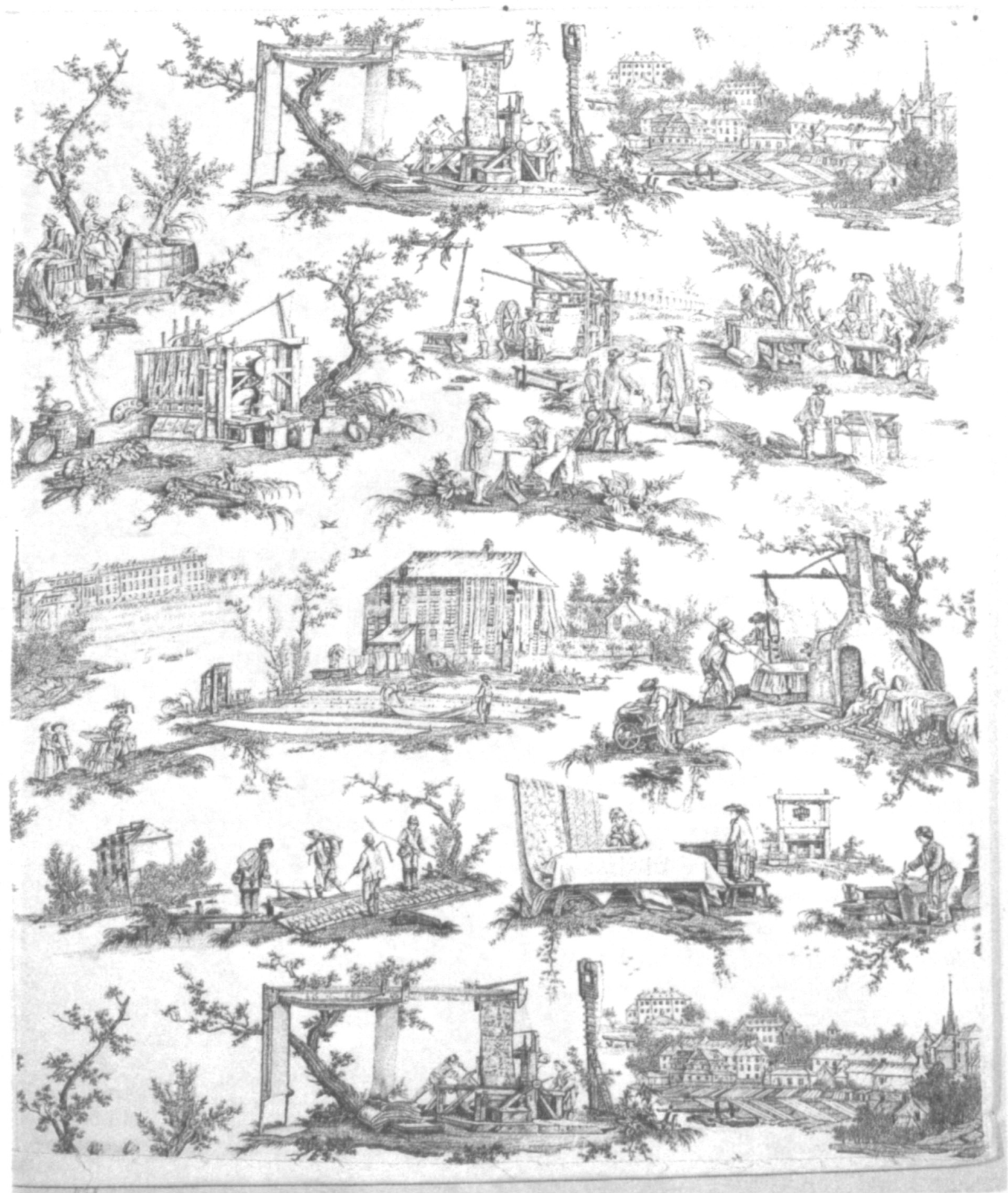

Figure 2. Details from "Les travaux de la manufacture (The Activities of the Factory)", designed by Jean-Baptiste Huet, plate print on cotton, 1783/1784 (Copyright: Muste de l'impression sur etoffes, Mulhouse). This design was commissioned by Oberkampf for his Jouy-en-Josas works. It shows all steps in calico printing (both block printing and plate printing), bleaching, washing, dyeing, etc. In reality, of course, the printing operations were performed inside a building. 
- Management, which was often carried out by the owner or his intermediary agent, sometimes subdivided into commercial and technical management, both of which could be run by a woman.11

- The duties of the designer or designers, who designed the samples, provided these were not purchased from outside. ${ }^{12}$

- The duties of the engravers, who made printing blocks with patterns based on the drawings. These operations were conducted according to a hierarchy. In larger companies, men, who cut the patterns, worked over women, whose work involved highlighting the details in the drawings with wire brads or studs (picotage, block pinning). ${ }^{13}$

- Another department produced the colours. Here lay the company's most important secret, which determined whether the printed colours were bright, pure and fast (resistant to scrubbing, washing or sunlight). ${ }^{14}$

- The printing workshop contained long tables on which sections of lengths of cloth were pinned in turn. The number of tables reflected the company's size and production capacity. Each table was used by both the printer and his assistants (teerers, tireurs). These teerers were usually children (girls or boys), who were hired by the printer (not by the proprietor). The printers had their own hierarchy. In polychrome

${ }^{11}$ Grau and Lopez, Empresari, pp. 42ff., list three different types of management in manufactures: (i) all shareholders participated in the management; (ii) division of labour between two owners, one of whom acted as commercial director, the other controlled the production department; (iii) management by only one person (an owner or an employee). For women as directors, see Waitzfelder, Der Augsburger Schille, pp. 114ff. (Madame Friedrich from Hamburg); Une femme d'affaires au XVIIIe siecle: La correspondance de Madame de Maraise, collaboratrice d'Oberkampf, ed. Serge Chassagne (Toulouse, 1981); Robert Peel married the daughter of his associate - she was in charge of the company's correspondence, see Chapman and Chassagne, European Textile Printers, p. 56.

${ }_{12}$ On the careers of these and the following skilled artisans, see Pierre Caspard, "Mon cher patron: Lettres d'un ouvrier suisse à ses employeurs, 1770-188", Milieux (October 1980), pp. 50-63, and idem, "Gérer sa vie: Etude statistique sur le profil de carrière des ouvriers de l'indiennage 1750-1820", Revue du Nord (January 1981), pp. 207-232.

${ }^{13}$ Joyce Storey, The Art of the Textile Blockmaker (Philadelphia, 1984). "Teams of girls making pin-work blocks from the late eighteenth century" are mentioned by Stanley D. Chapman, "Quantity versus Quality in the British Industrial Revolution: The Case of Printed Textiles", Northern History, 21 (1985), p. 178. Also see Berg, Age of Manufactures, p. 146. They are called "block pinners" at the Peel manufacture in Bury; see Chapman and Chassagne, European Textile Printers, p. 96.

${ }^{14}$ Doru Todericiu, 'Jean-Michel Haussmann 1749-1824, 'meilleur teinutrier de France' et pionnier de l'industrialisation de la chimie", Bulletin de la Societe industrielle de Mulhouse, 810, no. III (1988), pp. 25-27; Jean-Marie Schmitt, "Les établissements Haussmann de 1775 a 1830: Contours et reperes", Bulletin de la Sociéte Industrielle de Mullouse, 810, no. III (1988), pp. 13-21. For chemical research at the Oberkampf manufacture in Jouy-en-Josas, see Josette Brédif, Toiles de Jouy, p. 28. Pre-scientific dyeing techniques are explained in Emil Ernst Ploss, Ein Buch von alten Farben (Munich, 1967) and Jean-Richard, Kattundrucke, pp. 56-73. Many interesting operating instructions and scientific reflections appear in Ryhiner's manuscript. 
printing, first one (who determined the contours - le trait - of the pattern), then the next, and so on, would set up the printing blocks. More specifically, the printer responsible for the contour block was the imprimeur, while the other printers were called rentreurs. Some companies employed women (rentreuses) in the lower ranks of the printing process. ${ }^{15}$

- The printing process was complemented by painting operations, a women's trade. Women used brushes to highlight the printed patterns and to produce colours that the contemporary level of technology could not apply with blocks. These workers were called Pinslerinnen (pinceauteuses, pencilling women) (Figure 2). Larger companies either had their own rooms for these operations or had them performed off site. ${ }^{16}$

- The appropriate bleach requires no explanation, as it did not differ from standard bleaching surfaces (see Figures 1 and 3, foreground). The laundry essentially pertained to the bleaching operation, as the fabrics were repeatedly cleaned, both between and after the printing stages. Finally, the glazing machine and the staff involved were also important.

Manufacturing indienne was a seasonal business. During the period covered by this research, printing depended especially upon bleaching and washing, which entailed a shutdown during the colder months. ${ }^{17}$ As certain machines (such as washing machines and glazing machines) operated on water power, the low supply of water (or even freezing over) during the winter impeded standard operations. Not all manufactures closed during the winter. Production was often reduced along with working hours (in accordance with fewer hours of daylight), or the quality of printing might be simplified (such as with the impression $a$ réserve, which did not require bleaching). When business stopped, the earnings of those involved in printing, painting, bleaching and washing also ceased. The proprietors kept only the most skilled printers in their

is On women printers see Caspard, "Gérer sa vie". Turnbull, History, p. 204 referred to a manufacture in Hayfield: at 100 tables, 20 men printers and 80 women printers worked; in another manufacture in Spring Vale 56 women printers used to work (at 52 tables in the whole company). In 1810, in the Labarthe manufacture in Geneva, 21 men printers (imprimeurs) and 22 women printers (rentreuses) worked at 43 tables; in 1811 there were 50 imprimeurs and 48 rentreuses at 98 tables. The number of teerers (age 5 to 13) was the same as the number of tables: Archives d'Etat de Geneve, PH No. 5681.

${ }^{16}$ In 1790, Hamburg calico printing manufactures occupied 6,000 people, 1,000 of them were women who did pencilling (Schilderinnen), Rita Bake, Frauenerwerbsarbeit, pp. 50 , 246. Also see Pierre Caspard, "Les pinceleuses d'Estavayer: Stratégies patronales sur le marché du travail féminin au XVIIle siècle", Schweizer Zeitschrift für Geschichte, 36 (1986), pp. 121-156; idem, "Gérer sa vie", pp. 222-226, and Thijs, "Schets", pp. 157ff. "1) Bleachers were often seasonal workers, see Jan Lucassen, Migrant Labour in Europe 1600-1900: The Drift to the North Sea (London [etc.], 1987), pp. 83-86; p. 288, n. 79 mentions documents that regarded calico printing as migrant labour (also see following note). 
business throughout the winter through advances, promises or continued wages. ${ }^{18}$

Wage tables are useful, as they reflect both the hierarchy of the positions described and the differentiations within these tasks. They also highlight differences inside the image of a unitary working class. These tables show that designers earned more than engravers, while both types of workers differed from the others in the business in that they drew annual salaries. Printers might receive weekly wages, although they were usually paid according to their output. Salary scales varied by region and individual qualifications, and the highest salary could be ten times the lowest wage at a given manufacture. Skilled manufacture workers usually underwent training. As with artisans' work, a distinction therefore existed between the work of apprentices, journeymen and master craftsmen (there was some confusion regarding the definition of a master craftsman in the world of manufactures) versus labourers and assistants (manoeuvres). The actual wages also depended on the penalty system for flawed fabrics. The hierarchy thus reflected both the rank and with each position - the respective skills (and age to some extent), as well as the supply of and demand for certain knowledge on the labour market. ${ }^{19}$ Throughout this hierarchy of workers, gender-related wages

${ }^{18}$ Working hours have their own history. It is evident that work was longer in the summer than in the winter, and that more men and women were hired for the summer season than for the morte saison, e.g. at Dambrugge people worked from 6 a.m. to 7 p.m. in the summer (with a break at noon of $1 \frac{1}{2}$ hours), but in the winter only engravers and designers plus a few printers worked; their hours were from sunrise to 8 p.m. (two breaks, one of $1 \frac{1}{2}$ hours at noon, the other of half an hour in the afternoon), Thijs, Werkwinkel, p. 385. For Antwerp see Thijs, "Schets", p. 178. The Basel situation is reflected in Ryhiner's manuscript, see Dollfus-Ausset, Materiaux, p. 144. At the Neuchâtel manufactures, people worked in summer from 5 a.m. to 7 p.m. (breaks: half an hour in the morning, 11 hours at noon, sometimes half an hour in the afternoon); Pierre Caspard, "Die Fabrik auf dem Dorf", in Detlev Puls (ed.), Wahrnehmungsformen und Protestverhalten (Frankfurt, 1979), p. 109. At the Jouy works of Oberkampf, the morte saison lasted from November until March; Brédif, Toiles de Jouy, p. 70.

${ }^{19}$ See Fischer, Wirtschaft und Gesellschaft, pp. 242-257, 265ff., also Herbert Matis, "Über die sozialen und wirtschaftlichen Verhältnisse österreichischer Fabrik- und Manufakturarbeiter um die Wende vom 18. zum 19. Jahrhundert", Vierteljahreschrift für Sozial- und Wirtschaftsgeschichte, 53 (1966), pp. 433-476. Types of wages: though payment by piecework was customary for skilled workers, wages were paid every two weeks. Manoeuvres were mostly paid for time worked, although highly skilled personnel, such as chemists or designers, were hired for a year at a time. Thijs, Werkwinkel, pp. 371, 377, 378: wages for piece-work for designers, engravers, printers, and pinceauteuses at Dambrugge; Silvia Lausecker, Vor- und frilhindustrielle Produktionsformen am Beispiel der Seiden- und Baumwollindustrie in Wien 1740-1848 (Vienna, 1975), pp. 237ff.: annual wages plus extra pay per piece for engravers replaced payment for piece-work, later annual salaries for master printers, always payment by piece-work for journeyman printers; Caspard, "Fabrik", p. 127 for Neuchâtel: designers, engravers, overseers, chemists received annual salaries, both male and female printers were paid piece-rates, manoeuvres worked by the day. Wage rates for the Haussmann manufacture at Logelbach near Colmar appear in Schmitt, "Les établissements Haussmann", p. 14 (1780s): dessinateurs, 2000-6000 livres per year; maitres 
prevailed, which entitled women to only half the rate of pay of men for similar work. ${ }^{20}$

The larger a company, the more extensive its hierarchy became. It would have been impossible to supervise a large company without an overseer (to manage the workshop) and written factory regulations. At large manufactures, printers worked in groups of about ten individuals and each group had its own hierarchy. These workshops (societés or ateliers) existed for extended periods. A similar arrangement existed for pinceauteuses, who were hired in such groups. ${ }^{21}$

In Capital, Karl Marx accurately comments on the significance of disciplining workers at manufactures. As entrepreneurs in this industry were particularly dependent upon the goodwill of their workers, discipline was the main problem in running operations. In his 1766 manuscript, Ryhiner, a Basel manufacturer (Figure 3), advised that the duties of the director (directeur) of a manufacture were equivalent to those of an army general (géneral d'armée) with his troops. A measure of the importance of discipline among workers at large companies were the labour costs, which accounted for 50 per cent of the printing costs at indienne manufactures. A printing company's productivity depended on whether the overseer of the manufacture knew how to discipline his

graveurs, 1200-1500 livres per year; imprimeurs, maximum 20 livres per week; manoeuvres, 10 livres per weeks. For wages at Oberkampf's business in Jouy-en-Josas, see Brédif, Toiles de Jouy, pp. 70 and 72; also Chapman and Chassagne, Textile Printers, p. 180. Interesting wage tables in Thijs, Werkwinkel, p. 371 (1779). Walter Troeltsch, Die Calwer Zeughandlungs-Kompagnie und ihre Arbeiter (Jena, 1897), pp. 230-233 gives wages in 1777 for men and women; also interesting are the wages for the revolutionary period at Troyes (1793); see Henri-René d'Allemagne, La toile imprimée et les indiennes de traite (Paris, 1942), p. 14.

${ }^{20}$ In Jouy-en-Josas women accounted for a third to a half of the workforce; their rate of pay was half that of men: Brédif, Toiles de Jouy, p. 72. The standard ratio of wages between men, women, and children was about 4:2:1, see Marie Hofmann, Die Frauenarbeit in der niederösterreichischen Textilindustrie: Ihre Entwicklung in den ersten 100 Jahren bis 1848 (Vienna, 1940), pp. 49ff.; Gustav Otruba, "Zur Geschichte der Frauen- und Kinderarbeit im Gewerbe und den Manufakturen Niederösterreichs", Jahrbuch fur Landeskunde von Niederösterreich, 34 (1958-1960), p. 178; Reinhold Reith, Arbeits- und Lebensweise im städtischen Handwerk: Zur Sozialgeschichte Augsburger Handwerksgesellen im 18. Jahrhundert (Göttingen, 1988), p. 155. For nineteenth-century situations, see Gret Heer and Urs Kern, "Alltag der Glarner Tuchdruckereiarbeiter im 19. Jahrhundert", in Arbeitsalltag und Betriebsleben: Zur Geschichte industrieller Arbeits- und Lebensverhältrnisse in der Schweiz (Diessenhofen, 1981), p. 105. Women's careers in the calico printing industry were studied by Caspard, "Gerrer sa vie".

${ }^{21}$ Factory regulations from Dambrugge in Thijs, Werkwinkel, p. 367. Similar laws from Küpfer's Lorrach calico printing manufacture in Karl Herbster, Zur Geschichte der Lörracher Tuchindustrie von ihren Anfängen bis zur Mitte des 18. Jahrhunderts (Lörach, 1926), p. 44. At Jouy-en-Josas, printers formed ateliers, at Neuchatel, similar printers' structures were called societés, while groups of women printers formed boutiques, and pinceauteuses worked in formations called tables; Caspard, "Gérer sa vie", p. 219. 
workers and these conditions affected the size of companies. Clearly, it would have been difficult to manage more than about 1,000 workers. ${ }^{22}$

\section{MANUFACTURES AS A FIELD OF SOCIAL RELATIONS}

Manufactures were an eclectic field of social relations, including relations of power, solidarity, co-operation and competition. As this paper focuses

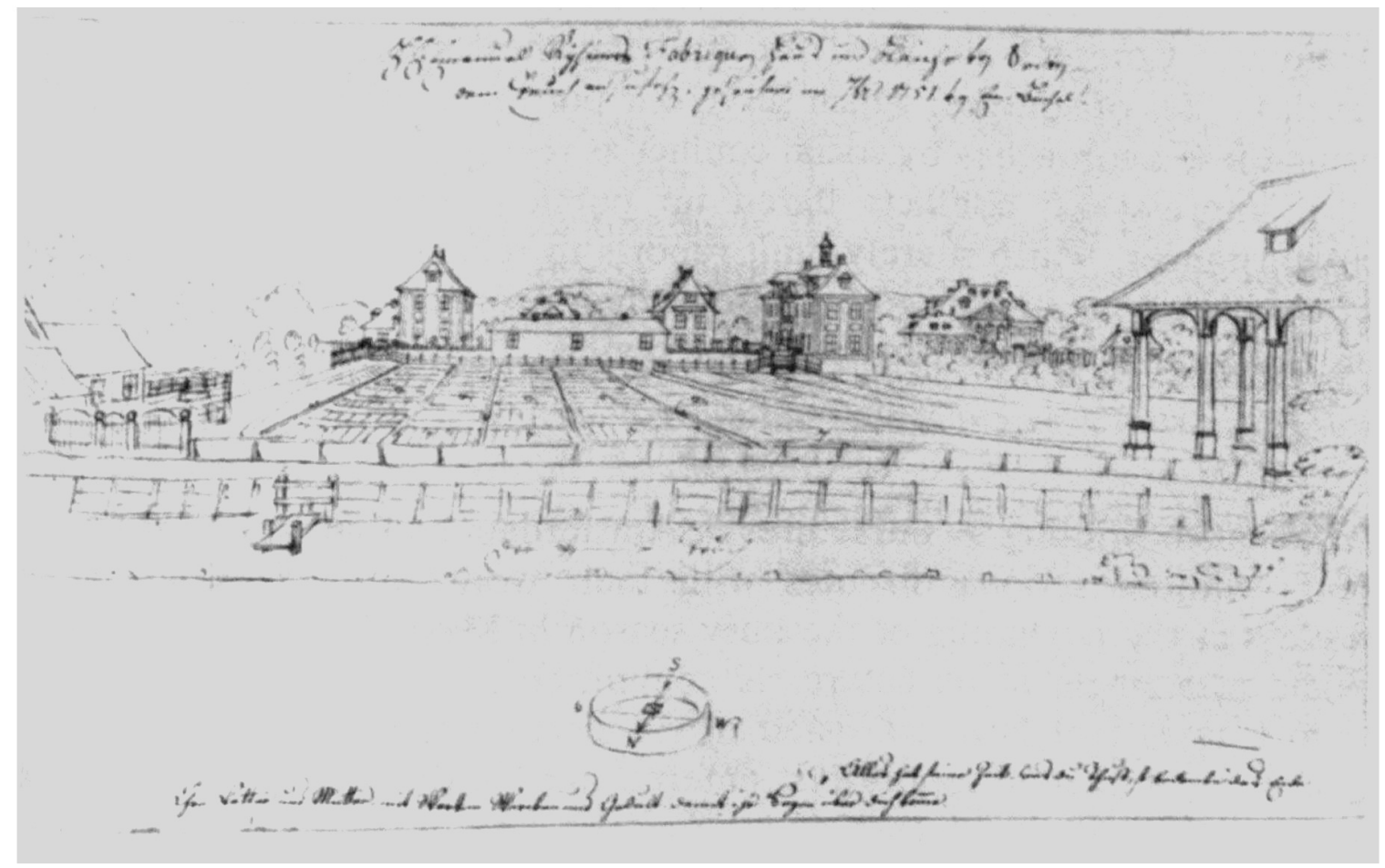

Figure 3. Calico printing manufacture and bleaching grounds of Mr Johannes Ryhiner near Basel, by Emanuel Büchel (1751) (Copyright: Staatsarchiv Basel-Stadt, Bildersammlung Falk. Fb 1, 3)

22 "Since handicraft skill is the foundation of manufacture, and since the mechanism of manufacture as a whole possesses no objective framework which would be independent of the workers themselves, capital is constantly compelled to wrestle with the insubordination of the workers. [. . ] Hence the complaint that the workers lack discipline runs through the whole of the period of manufacture." K. Marx, Capital, vol. I, trans. B. Fowkes (Harmondsworth, 1976), pp. 489-490. Ryhiner's opinion in Dollfus-Ausset, Materiaux, p. 67. On the cost of labour, see e.g. Caspard, "Fabrik auf dem Dorf", p. 106; Stanley David Chapman, The Cotton Industry in the Industrial Revolution (London, 1987), p. 47. Sizes of manufactures: in 1805, Jouy-en-Josas had 1021 ouvriers: 3 designers, 5 engravers for copper plates, 40 engravers for wooden blocks, 30 picoteuses, 175 printers (men and women), 190 teerers (both sexes), 10 printers specializing in copperplate printing, and 570 pinceauteuses, Josette Brédif, Christophe-Philippe Oberkampf et la manufacture de Jouy-en-Josas (Colmar, 1987), pp. 15 and 170 . Haussmann employed 400 workers at his Logelbach works near Colmar in 1777 and 1,000-1,200 in 1786 (i.e. 125 tables); Schmitt, "Les établissements Haussmann", pp. 15-23. The largest number of employees we know of is reported for Schulle's manufacture at Augsburg: 3,500 workers for 1780, or 10 per cent of the inhabitants of Augsburg, Waizfelder, Der Augsburger Schille, p. 111; Ruth Schillinger, Die wirtschaftliche Entwicklung des Stoffdrucks (Cologne, 1964), p. 
on (internal) relations, it overlooks the (external) relations between entrepreneurs and the craftsmen hired for their Verlag, who were officially independent artisans. For example, it does not examine the wellknown conflict between the weavers' guild and Johann Heinrich von Schüle of Augsburg.

Further research will show that, while the subsequent restriction of this field of study to selected branches of manufactures may be deplored, it offers tremendous advantages, especially when applied with some flexibility. Conflicts are ideal for studying these relationships. Disputes result in files of sources, which serve our purposes admirably. Obviously, using these approaches by social conflict as research standards may create false impressions: conflicts flared up publicly only under exceptional circumstances, which merely limit reports to relationships that otherwise would have gone unnoticed because of their everyday nature. The reports on two similar disputes merit closer review.

\section{AMSTERDAM $^{23}$}

After calico printing manufactures in Amsterdam had operated for fifteen years without serious disputes with their workers, the printers grew restless at the beginning of the busy season in May 1744. The movement began at a single manufacture. A committee of printers led the protest from a tavern (it later consisted of six elected leaders).

The movement's supporters entered the other printing shops and ordered that all work cease as long as the rate of pay and the number of apprentices did not meet the guidelines that the committee had recorded on the basis of previous agreements. As anyone who continued to work was threatened with violence, journeymen who were satisfied with their bosses also had to abandon their tasks. Any workplace where operations continued fell into disrepute and was declared dishonest. Within a week, fourteen manufactures yielded, while six continued as dishonest and were subject to strikes.

The dispute erupted as a result of a company that employed a higher ratio of apprentices to journeymen than the journeymen tolerated. It flouted the stipulation of only one apprentice for every seven journeymen at the workplace.

The leaders of the movement tried to extend it outside Amsterdam. Journeymen wrote to colleagues in other towns to request support in

20 mentions 1,500 workers, which seems more reasonable. Haussmann produced 50,000 printed pieces per year with a workforce of 1,000 people; Schule printed 70,000 pieces. 23 W. J. Smit, De Katoendrukkerij in Nederland tot 1813 (Rotterdam, 1928), pp. 131ff., 261ff.; Rudolf Dekker, "Labour Conflicts and Working-Class Culture in Early Modern Holland", International Review of Social History, 35 (1990), pp. 397-400, and idem, "De staking van de Amsterdamse kantoendrukkersknechts in 1744", Textielhistorische Bijdragen, 26 (1986), pp. 24-38. I have to omit some details here and in the Basel case, below. 
their protest. The rebels used St Crispein's pub as their centre, and held their meetings, conducted committee work and formulated their demands there. They also printed and distributed a manifesto.

The journeymen consistently avoided unyielding companies. Anyone deprived of earnings because of his direct or indirect (i.e. apprentices) involvement received support from a common cash box (gemene beurs). The managers of the companies affected by the strike were pressured by merchants with unfilled orders. Three eventually submitted a petition to the authorities. Then the town government stepped in and arrested several printers by dragging them from their beds during the night and imprisoning them as ringleaders. It imposed a strict mandate on the movement. Participants were threatened with execution for rebellion, and a reward was offered for turning in the instigators of the movement. The ringleaders received prison sentences ranging from two to three weeks, and one journeyman was banned from the city for two years. St Crispein's was vacated, and the companies resumed operations. This dispute was the last major conflict among calico printers in Amsterdam, as competition from abroad in this industry increased, leaving many journeymen unemployed. The boom of the first half of the century ended, and the surplus of workers weakened the organized journeymen and toned down the disputes.

During the preceding period, a distinction had existed in the Amsterdam calico printing industry between merchants, who supplied the fabric and took back printed goods, and the masters (printing entrepreneurs), who used journeymen and apprentices at their manufactures to do the printing. These manufacturers possessed little reserve capital. They had to resolve labour disputes, which occurred frequently during the industry's heyday from 1690 to 1740 , quickly for the sake of business. Otherwise, it became impossible to satisfy the merchants' demands. These conditions and the dearth of skilled printers during the period of expansion gave the printers better leverage. The Dutch tradition of settling labour disputes peacefully through court-like meetings and mediators provided a quasi-institutionalized framework (although it lacked approval by the authorities). ${ }^{24}$ Following a short labour dispute in 1729, a new method was used to eliminate the main cause for disputes through a collective, notarized agreement between 500 journeymen and 26 masters. This agreement officially set the ratio of journeymen to apprentices at 7 to 1 and mandated a rate of pay for piece-work for all varieties generally printed at manufactures. The town government sanctioned this agreement. As calico printing was a "free trade" in Amsterdam, their conditions were not subject to regulations by guilds or by any board established by the town government. Thus, the course of relations at these manufacturers depended largely on the balance of power between entrepreneurs and workers.

${ }^{24}$ See Dekker as quoted above for these institutions. 
The great conflict of 1744 resulted from the violation of the convention of 1729 . In this light, it was understandable why the printed, allegedly subversive pamphlet was merely a reminder of the stipulations of 1729 , complemented by additional rates for piece-work for over fifty new kinds of printed material, which had probably appeared in the interim. Finally, the pamphlet explained that the journeymen wished to retain the official 7 to 1 ratio of apprentices to journeymen.

\section{BASEL ${ }^{25}$}

On the morning of 23 October 1794 (i.e. towards the end of the busy season), the printers and block engravers at the new Werthemann manufacture laid down their work. The printers and engravers had heard that the entrepreneurs had recently joined forces in approving an arrangement which put them at a serious disadvantage. The workers quickly discovered the nature of this arrangement: henceforth, no calico printing manufacture in Basel could hire a worker away from another proprietor in town without his explicit agreement. Should a worker quit a Basel manufacture, he would have to wait six months before obtaining employment at another local company. An additional stipulation concerning printers specified that if the month appeared in letters on a worker's discharge slip, the former employer granted permission for his or her transfer to another factory in Basel. Should the month be abbreviated in figures on this form, then no proprietor in Basel was allowed to hire that worker.

The workers that had gathered at the Werthemann premises unanimously decided to "stand together" and to cease work in protest of this agreement. At unanimous request, a worker wrote down their protest and stated that this arrangement put them completely at the mercy of the proprietors, that the workers would not tolerate such "slavery" and "tyranny" and were therefore abandoning their work.

Following an unsuccessful attempt by a clerk at appeasement, two workers alerted the staff in the neighbouring factory. The workers at that factory sent a delegation to another factory to convince the staff members to lay down their work as well, and so on. All printers gathered in front of a tavern called the Schwarze Adler, which was too small to accommodate the 200-300 workers. They decided to meet at the Rebhaus, a social hall belonging to one of the three citizens' corporations of Kleinbasel..$^{26}$

The meeting at the Rebhaus proceeded in an especially orderly fashion. The engravers and printers sat at six different tables according to manufacture. Then they ate and drank (their afternoon break). Afterwards,

${ }^{25}$ Simon, Wollt Ihr Euch der Sklaverei kein Ende machen?

${ }^{26}$ Translator's note: the area of Basel on the right bank of the Rhine. 
they discussed the entrepreneurs' arrangement and their course of action, and again, they recorded their arguments. Unanimously, they decided to cease work until the entrepreneurs retracted their agreement. They elected a committee consisting of one or two deputies from each staff, they drafted a letter to the chairman of the factory commission of the town authorities, to be delivered by the committee, and all present swore to stick together and to protect the names of the authors of their documents.

Meanwhile, the engravers still working for two manufacturers received a note calling on them to join the strike ("according to which they eschew all tyranny and wish to destroy slavery, [...] it is also said that they do not wish to live under pressure or anything like it"). That evening, the president of the factory commission received the delegation elected in the tavern. He promised to launch an investigation into the agreement if they suspended their strike.

The next day, the committees that had spoken with the president of the factory commission met again. Operations remained at a standstill, even though a few proprietors tried to convince their workers to suspend the strike. Werthemann, where the strike began and who had the most reason to obtain and retain workers, reached a formal agreement with his printers and engravers in which he promised to enable workers to quit. In return, the workers promised "that they would behave peacefully, work for me [Werthemann] with honesty, diligence and loyalty, and refrain from participating in any future unrest".

The next day, work resumed virtually everywhere, and the special session of the factory commission was held, as promised by the president. In court-like proceedings, the plaintiffs (i.e. the six delegates of the printers and the engravers) were heard first and were given ample opportunity to voice their reproaches. Next, the six factory owners were heard as respondents. The commission deemed the workers' protest justified, as the agreement unilaterally placed them at a serious disadvantage. The commission objected, however, to the work stoppage. It prohibited the entrepreneurs from enacting similar arrangements without notifying the workers and the authorities in advance. The strike ended successfully and was not resumed when three workers were arrested and tried as ringleaders at the instigation of the town government - probably upon the request of a factory owner, who felt insulted by a worker, and of the town council, which sensed greater evil than a labour struggle behind the words "tyranny" and "slavery". The three (alleged) ringleaders were released with a warning in return for payment of the costs of imprisonment.

\section{SEPARATE OPERATIONS IN DISPUTES AND SOLIDARITY}

It is striking that virtually all reports on these larger movements concern revolts by printers and readers of the reports must wonder whether any 
positions existed in the company besides those for printers. This observation is significant, as a movement on the part of the printers must have affected employees in other positions as well, whose own interests might very well have differed from those of the printers.

The scarce reports on movements by women, who made demands concerning their own workshops, are even more interesting. They reported their concerns in the same way that men did. Pierre Caspard wrote about a petition submitted by pinceauteuses who worked in Estavayer (along the shore of the Lac de Neuchâtel across from the headquarters, i.e. the Fabrique Neuve in Cortaillod). In 1787 and in 1796, they threatened in a collective letter to the proprietor to stop working unless their wages were raised to compensate for harder or more exhausting work. Although such incidents were rare among calico manufacturers, cases exist in other industries of collective efforts from the lower ranks of manufactures to secure or raise their wages. ${ }^{27}$

Thus, it appears that workers from each position generally defended their own interests and, while this situation does not preclude solidarity among different groups, ${ }^{28}$ it may create special problems. For example, most engravers of Basel refused to join the printers' strike in 1794. While the protesters were prepared to demand solidarity from those in their own profession, as far as the engravers were concerned, they merely sent a note for the persons concerned - they refrained from calling on the engravers. ${ }^{29}$

Within a single profession, such as among printers, overt or indirect threats of violence frequently served to create the temporary appearance of a closed, collective movement. Admittedly, this method required forcing individuals to participate whose jobs might differ slightly from those of the strikers, such as the apprentices.

Sentiments of solidarity were usually restricted to workers at similar levels in the hierarchy with a similar degree of skill. As each workshop or company employed workers with different qualifications, this solidarity that was channelled towards protest emanated from those practising the same trade.

27 Caspard, "Estavayer", p. 146; Caspard, "Fabrik auf dem Dorf", p. 136; Rudolf Weinhold, "Meister - Gesellen - Manufakturierer: Zur Keramikproduktion und ihren Produzenten in Sachsen und Thüringen zwischen 1750 und 1850", in idem (ed.), Volksleben zwischen Zunft und Fabrik (Berlin, 1982), p. 210, for example of the day labourers at the wood shop in the Meissen porcelain works. Bake, Frauenerwerbsarbeit, p. 121 wrote about a women's strike in the Metsch batiste manufacture at Stockerau. Other protests by women can be found in the records of the Commission des fabriques de Mulhouse (see my forthcoming book on conflicts in manufactures).

2 In another example from the porcelain manufacture in Meissen, painters went on strike for an allowance for high cost of living in 1761. They were immediately joined by the throwers and the moulders; Weinhold, "Meister", p. 208. On the other hand, apprentices were forced to join the strikers in the Mosney riot, see Turnbull, History, p. 185.

${ }^{29}$ Simon, Wollt Ihr Euch der Sklaverei kein Ende machen?, p. 74. 


\section{TYPES OF ACTION}

The actions were standardized, but to designate them as "ritualized" would belie the rational manner of the procedure. In cases of dispute, individuals of different origins at different times and places resorted to the same codes of behaviour. Various forms of this phenomenon appeared across communities that entered disputes with the authorities or their neighbours and campaigns that were decades apart and widely dispersed began and progressed in very similar ways.

One possible explanation might be that (1) certain traditions persist in cultures of the lower social strata, even if they are not immediately apparent through conduct. Consequently, the links that stick in people's memories and explain the similar forms of action usually remain hidden. The behaviour of skilled journeymen, workers, community members or women fishmongers is similar with respect to their participation in a given social group subject to related power structures. Another possibility was certainly (2) that one social group copied the behaviour patterns of another group. As described above, the patterns of behaviour and organization among the journeymen were most likely to have served as examples for the manufacturing industry. Finally, it is reasonable to assume that (3) comparable problems in industries and situations led to similar forms of conduct. According to Marxist tradition, forms of protest and labour organization are usually based on production methods and structures. ${ }^{30}$

As for guilds and other forms of craftsmen's organizations, workers at manufactures appear to have aspired to a similar social status and to have complied with the resulting code of honour. Therefore, they would also have copied their organizations to distinguish themselves from servants and assistants or day labourers, whose status was considerably lower. As the most skilled workers most frequently resorted to collective action and as they improved their skills in part through long journeys, it is necessary to consider the traditions of protests specific among migratory skilled workers.

Occasionally, actions were deliberately launched at judiciously chosen points in time. Economic and seasonal conditions in which entrepreneurs relied on every worker were particularly effective times to present demands emphatically. Here, rational calculations prevailed, revealing insight, access to information and experience. ${ }^{31}$

${ }^{30}$ For riot traditions in rural communities, see Peter Blickle, Unruhen in der ständischen Gesellschaft 1300-1800 (Munich, 1988), with bibliography. On workers' organizations other than traditional guilds, see Berg, Age of Manufactures, p. 87; Prothero, Artisans and Politics; Dobson, Masters and Journeymen; John Rule, The Experience of Labour in Eighteenth Century Industry (London, 1981), and idem, The Labouring Class in Early Industrial England 1750-1850 (London, 1986). Workers from manufacturing trades got their own guild through Prussian authorities, e.g. master weavers working under a puttingout system, see Kriger, Manufakturwesen, p. 535.

${ }^{31}$ Krüger, Manufakturwesen, p. 519; Simon, Wollt Ihr Euch der Sklaverei kein Ende machen?, p. 55; Rule, Experience of Labour, p. 178; idem, Labouring Classes, p. 261. 
Collective petitions were an important method, which involved drafting a document that presented demands to the management. They might introduce an action, serve as a component of or even as the entire action. Depending on the environment of political rule, petitions might address rulers (such as the king of Prussia) or a town council. This act was unpleasant for entrepreneurs, as it placed decisions on issues pertaining to their turf outside their control..$^{32}$ In addition to petitions, assembling during working hours was a common form of action. This method was not initially a strike. People simply left work to gather elsewhere to discuss concerns and forms of protest.

Despite assertions to the contrary, it became clear that, for those with similar skills, these actions were not voluntary, but imposed through threats of violence or denouncement of a company or its employees. Entrepreneurs received threats of violence if they resisted the will of the organized workers. Non-violent principles were virtually absent from the legitimation of protest methods in the eighteenth century, although this ideology did appear in entrepreneurial denouncements of the workers' allegedly criminal conduct. These proprietors viewed both the forced participation and the coalition of workers as violence and as dangerous conspiracies against municipal peace and the social order at work..$^{33}$

These meetings took place at certain inns or at specific outdoor sites and the orderly and organized nature that prevailed in these gatherings was striking. A regular chairman presided and the participants were assigned to departments according to their job title and to the companies where they worked. Apparently, these meetings were not just held to prepare current actions. Locations frequented by workers at calico printing manufactures were already organized in this manner. These structures consisted of officers, boxes for documents, cash boxes and - as mentioned above - public houses. Everything about these facilities, including the terms used, resembled journeymen's guilds. There were records of decisions and claims mentioned if petitions were used in a protest.

Another method of preparation for protest was highly reminiscent of preparations for community uprisings during the early modern era: the election of committees to co-ordinate operations during the discussions and to negotiate with employers and authorities as the authorized representatives of professional groups. The resolutions reached at the meeting were binding to everyone exercising that trade in the area in question.

${ }^{32}$ See, for example, Krüger, Manufakturwesen, p. 516.

${ }^{33}$ See Rule, Labouring Classes, p. 263; idem, Experience of Labour, p. 184. In 1786, eleven people signed a letter notifying the proprietors of their solemn oath to set fire to the manufactures in Mosney and Manchester, because cylinder printing machines had been introduced that ruined the "trade" of the journeymen printers; Chapman and Chassagne, European Textile Printers, p. 31. 
A strike could be one of these decisions. In this case, the collective general attitude to work became imbued with determination to persist until the other side yielded. As this strategy appears in resolutions as a deliberate option, it seems justified to designate these measures as strikes, except if strikes indicate only actions aimed at social revolution, as became possible with the workers' movement during the industrialization of the nineteenth century. Obviously, these strikes have to be distinguished from simple desertion and calls to abandon work to achieve a gathering with the best attendance possible. As these examples of collective actions are taken only from the late seventeenth to the end of the eighteenth century, it is impossible to verify the progression from workers' walking out from one city to actual strikes, as maintained by Rudolf Dekker for Holland. According to my concept of strikes, the action must not only be collective, but must also result from discernible organization. It also assumes that the action taken expresses deliberate protection of interests and strategic considerations. Furthermore, these strikes occurred in a capitalist context where labour relations were defined by a rather free labour market. ${ }^{34}$

In addition to meetings and forms of action to be chosen there, calico printers also resorted to damaging machines. Cases in England reveal that a possible response to technical innovations in textile printing that threatened the established order of skills and income involved rather ritualized destruction of this equipment (or threats to that effect). In Geneva, printers rendered the printing plates unusable (by destroying the engraving), claiming that they were too large, so that printers would earn less than with smaller plates. The introduction of the printing cylinder in the Manchester region suffered the same fate. This type of

${ }^{34}$ On strikes in the calico printing industry see, besides Simon, Wollt Ihr Euch der Sklaverei kein Ende machen?, and Smit, Katoendrukkerij: Dekker, "Labour Conflicts"; Turnbull, History, p. 184; Dobson, Masters and Journeymen, p. 16 (also his list, p. 164). Contemporary texts seldom used the term "strike". Rather, they mentioned people walking out of the workshop, or "abandoning their duties"; authorities and entrepreneurs used terms like "riot", "tumult", "insurrection", "mutiny", "conspiracy", "combination". Since 1763, "to strike" entailed "a concerned refusal to work by employees till some grievance is remedied", Dobson, Masters and Journeymen, p. 19. Dobson showed statistics for labour disputes in London, pp. $42-44$ for the years 1718-1800. For the role of traditional workers' organizations in labour conflicts in France, see Sewell, Work and Revolution, p. 32. For England, see Chapman and Chassagne, Textile Printers, p. 98. The modern terms "strike" and "labour movement" were discussed by Klaus Tenfelde and Heinrich Volkmann (eds), Streik: Zur Geschichte des Arbeitskampfes in Deutschland während der Industrialisierung (Munich, 1981). My conception of strike follows the one described by Tenfelde and Volkmann, pp. 13, 17, although I deliberately ignore the context they presupposed. It is not obvious that all artisans' riots in guilds like those in the German Reich should be called strikes, see Rainer S. Elkar (ed.), Deutsches Handwerk im Spätmittelalter und früher Neuzeit (Gottingen, 1983), p. 24; Wilfried Reininghaus, Die Entsteluung der Gesellengilden im Spattmittelalter (Wiesbaden, 1981), pp. 10ff. for research traditions in this field. 
action required powerful organizations, which were no longer ubiquitous by the economic crisis of the Napoleonic era. ${ }^{35}$

\section{CAUSES AND ARGUMENTS}

Obviously, both workers' protests and entrepreneurs' positions required explicit justification and it is reasonable to assume the formulation of grounds and entire arguments. Occasionally, they appear in documents that have survived the centuries. The written arguments are a particularly valuable complement to the court records, which do not present a clear picture of what people actually did and said.

\section{CIRCUMSTANCES}

These texts bear witness to the existence of areas of conflict that frequently disrupted the relations between entrepreneurs and skilled workers (sometimes also female workers). They mention the following issues:

- Accommodations: workers employed by manufactures often had to choose between a place to sleep on the manufacturing premises and lodgings in a house in the village or town. While the first type of accommodation basically turned the workers into kinds of institutional inmates, the alternative involved all the problems resulting from shortage of space in a tightly populated settlement, including rising rents. ${ }^{36}$

- Apprenticeship: the entrepreneurs concluded training agreements, some before a notary public, others as simple agreements. Virtually all documents on file about labour disputes at calico printing manufactures mention apprentices who left before completing their contracts, because of poor accommodation, abuse from journeymen or masters, or other reasons. Furthermore, the number of apprentices and the work assigned to them caused disputes between journeymen and their employers. ${ }^{37}$

- Form of payment: it was critical whether employees received their wages in good or bad money and whether this payment was in money or in kind. Disputes arose especially frequently concerning the custom among entrepreneurs of holding back part of the wages until completion of the agreement. ${ }^{38}$

${ }^{35}$ Archives d'Etat, Genève, "Minutaire" of the "notaire" Jean-Louis Duby 1760, vol. 4, pp. 26-28, 11 May 1732 (PC 3494).

${ }_{36}$ Caspard, "Fabrik", p. 121.

${ }^{37}$ The abundance of examples precludes a detailed quotation. See the notary public records in the Archives d'Etat de Genève. Also see documents from the Cortaillod printing works at the Archives d'Etat de Neuchâtel, Fonds Fabrique Neuve, as well as from the Amsterdam case described above.

${ }^{38}$ Brédif, Toiles de Jouy, p. 70; Jean-Marie Schmitt, Aux origines de la révolution industrielle en Alsace: Investissements et relations sociales dans la Vallée de St-Amarin au XVIIIe siecle (Strasbourg, 1980), p. 367. 
- Income levels: in keeping with their views on fair economics, workers always demanded wage levels sufficient to cover their cost of living. This demand reflects the principle of real wages (ante verbum), which conforms to the popular principle of subsistence or pressing need (Nahrung). ${ }^{39}$

- Details concerning the termination of employment relationships: one of - the most frequent causes of conflicts was the attempt by employers to force workers to take receipt of a certificate of discharge upon leaving a firm and to present this form upon employment at a new company (congé, Abscheid). Entrepreneurs applied this method, frequently with government support, to control the labour market and to limit opportunities for wage increases as a result of switching jobs. ${ }^{40}$

- Precautions for the slow season: which employees did entrepreneurs retain during the unproductive period in the winter, and under what conditions? Which employees were subsequently rehired after that period? Employers often demanded concessions from their workers in return for the additional expense of keeping them on through the winter. ${ }^{41}$

- The ultimate authority in determining the nature of the staff in the company: this was the work performed by apprentices and women. Frequent causes of disputes involved attempts by employers to reduce the cost of wages by hiring more women and apprentices or efforts by skilled workers to prevent this tendency and to obtain control over the company's policy of hiring. The struggle against work done by both apprentices and women included listing specific working procedures or

${ }^{39}$ Theories of subsistence orientation and leisure preference will not be discussed here. Examples appear in Caspard, "Fabrik", p. 136. Workers wanted to earn enough during the summer to cover their cost of living during the winter. See, for example, Weinhold, "Meister", p. 207.

to The Basel case of 1794 resulted from one of these certificates (see above). The same way of inserting messages into this form was used in Prussia; see Rolf Straubel, "Bemerkungen zum Verhalltnis von Lokalbehörde und Wirtschaftsentwicklung: Das Berliner Seiden- und Baumwollgewerbe in der zweiten Hälfte des 18. Jahrhunderts", Jahrbuch für Geschichte, 35 (1987), p. 142. For the introduction of these forms in Prussia (in 1769) and Austria, see Krilger, Manufakturwesen, p. 280, and Lausecker, Produktionsformen, p. 105. In England, the Great Turnout of the calico printers was caused by the introduction of discharge papers by a group of entrepreneurs in 1790; Turnbull, History, p. 185. A similar agreement between proprietors in Geneva aimed to improve control over workers trying to leave the manufactures before completing their contracts, Archives d'Etat de Genève, Commerce A5, Ve registre (1729-1740), pp. 23-27 (16 December 1729). In Nantes, an entrepreneur was fined for engaging a printer without asking for his billet de conge: Bernard Roy, Une capitale de l'indiennage: Nantes (Nantes, 1948), p. 159. Horst Gellbach, Arbeitsvertragsrecht der Fabrikarbeiter im 18. Jahrhundert (Münster, 1939), p. 25 , viewed the conge as a replacement for similar but verbal practice among artisans, Abdingen.

"Simon, Wollt lhr Euch der Sklaverei kein Ende machen?; see also the Ryhiner manuscript. 
products that only fully skilled, male workers were allowed to perform or produce. Women were a dangerous source of competition for men, as they obviously earned far lower wages. Efforts by organizations of skilled men primarily strove to prevent women from taking over work done by them. Although fathers and husbands had good reason to want their daughters and wives to earn an income at manufactures, it should not jeopardize their own wages. In addition, printers often complained that entrepreneurs hired too many apprentices, either to propagate knowledge of the trade in the long run, or to reduce production costs over the short term. The refusal by skilled workers to cultivate their own competition by passing on their knowledge to many apprentices reflects the proverbial "abuse" of the old guild system. In fact, entrepreneurs repeatedly tried to replace journeymen with apprentices. By the end of the eighteenth century in England, many apprentices were actually young unskilled workers (euphemistically called "outdoor apprentices") performing the tasks of journeymen. ${ }^{42}$

These issues became especially urgent in certain circumstances, including situations of expansion or contraction in the industry that affected the labour market, both the aforementioned seasonal trends in the trade and periods of overall subsistence crises (inflation).

\section{STRATEGIES OF LEGITIMATION}

The documents contain arguments to justify requests. The methods of argumentation were as follows:

- The legal basis for discourses of legitimation was crucial. Nevertheless, it did not usually rest on written or decreed law, but rather on local custom in the industry (from which the respondent had deviated), or

${ }^{42}$ Women's situation: Berg, Age of Manufactures, pp. 146, 151; Lausecker, Produktionsformen, p. 78; Hoffman, Frauenarbeit, p. 82. Men against women: Serge Chassagne, La manufacture de toiles imprimées de Tournemine-les-Angers, 1752-1820 (Paris, 1971), p. 266; Roy, Nantes, pp. 176, 204. In Montpellier, skilled workers told the proprietor: "They would prefer to quit rather than to train any apprentice, whether male or female"; proprietors believed the conspirators wore a small dauphin made of silver, Alain Chante, "L'indiennage à Montpellier au XVIIIe siècle" (Mémoire de maîtrise, Montpellier, 1972), pp. 216, 217. Masters and journeymen against apprentices: complaints about workers refusing to train apprentices were even found in the Dictionnaire des Arts et Métiers (1766), see D'Allemagne, Toile imprimé, p. 12. In Rouen, printers struggled to prevent their bosses from taking on apprentices. Information exists about similar "conspirations" in Orange (1760), Darnétal (1773), Beauvais (1778); Serge Chassagne, "La naissance de l'industrie cotonnière en France 1760-1840" (Thèse Paris, Lille, 1986), pp. 236, 242. On outdoor apprentices: Rule, Experience of Labour, pp. 100, 115; Chapman and Chassagne, Textile Printers, p. 95. On limited number of apprentices: Smit, Katoendrukkerij as above, also see Turnbull, History, pp. 186, 189; Krüger, Manufakturwesen, p. 530; Straubel, "Lokalbehorde", p. 141; F. W. Carter, "The Cotton Printing Industry in Prague 17661873", Textile History, 6 (1975), p. 133; Rule, Experience of Labour, p. 115. 
on the often-evoked established convention. The supposed or actual conditions of this type mainly concerned working hours, issues of pay and dismissal, as well as problems with work performed by women and apprentices as discussed above. Again, it is obvious that current interests at least partially determined the formulation of alleged old usages. Arguments could have a solid basis that explicitly addressed agreements reached upon hiring or general practices. A weaker basis might target general views on just economic order. ${ }^{43}$

- Collective agreements certainly occurred: as we have seen, in 1729, the textile printers in Amsterdam tried to set a collective agreement with local entrepreneurs in writing. Their success was temporary, as this arrangement did not benefit all entrepreneurs equally (so that they did not all stick to the agreement). It is also likely that the collective agreement merely reflected the achievements resulting from the dispute, which were subject to revision at the next opportunity.

- Apart from arguments based on current standards and agreements in the industry, it was common to resort to general views on human decency that were supposed to prevail in the relationships between ranks in the company hierarchy. The workers demanded that their work enable them to subsist. This "subsistence orientation of workers" pertained to the "plebeian culture". An appreciation of this principle is crucial to understanding the "dynamics of this period of manufactures or proto-industry." An excessively anthropological analysis of the relationships observed should certainly not exclude the desire for higher wages and internalized labour discipline prior to full implementation of capitalist industrial conditions. ${ }^{45}$

- Other important factors include respect and self-esteem, along with the conditions necessary to express these sentiments to avoid diminishing self-esteem. Therefore, skilled workers often mentioned "tyranny" and "slavery": freedom to change place of employment, no visible social discipline, their own collective rights to distinguish them from other groups (such as servants and day labourers), and wages enabling them to live according to their reasonable expectations. During the eighteenth century, the "slavery" argument frequently appeared in pamphlets as well as in rural and plebeian/urban environments (this

${ }^{43}$ See below.

4t Berg, Age of Manufactures, p. 83.

15 For some aspects of this discussion, see Martin Henkel, Zunftmißbräuche: "Arbeiterbewegung" im Merkantilismus (Frankfurt, 1989), pp. 10, 57, 140, 147, 314. He attacked authors who believed that workers before the nineteenth century were unable to learn from experience where their interests lay; see Andreas Griessinger, Das symbolische Kapital der Ehre: Streikbewegungen und kollektives Bewußtsein deutscher Handwerksgesellen im 18. Jahrhundert (Frankfurt, 1981). Also see the suggestions of E. P. Thompson, "English Trade Unionism and Other Labour Movements before 1790", Bulletin of the Society for the Study of Labour History, 17 (1968), pp. 19-24. 
could not be verified for earlier centuries). In the case of rural tenants (serfs), the word connoted serfdom and feudal obligations. The language clearly predates the events and publications of the French Revolution, even if more documents exist from after 1789. The different categories include (a) a strong political emphasis on the mention of "slavery", (b) a more plebeian-social-economic one, and (c) a discourse of protest from the perspective of (rural) subjects.

(a) Examples of the political emphasis on "slavery" as the degradation of simple citizens of a government with absolutist tendencies appear in the Republican "freedom" discourse. Classical positions may be found in The Chains of Slavery by Marat (1774), the later revolutionary, as well as in an article from a 1776 issue of Ephemeriden der Menschheit by Swiss enlightenment philosopher Isaak Iselin (1774): "I see no potentate over me or around me who is able to affect my honour or my life at will with impunity. Therefore, I do not believe I am a slave." ${ }^{46}$

(b) Plebeian and socio-economic definitions are not entirely unrelated. Both protest at being treated as "serfs" or as full dependents of a lord. They also share the frequent claim, that they deserve protection from economic exploitation and that the decline into poverty is not imminent. Excellent examples include the speeches by the calico printers of Basel to the local factory commission deploring entrepreneurial conduct. The key word "slavery" appears in only one discourse, addressing the block engravers, rather than the representatives of the authorities: "Do you not wish to end slavery?" the printers asked the engravers when the latter declined to join the protest of $1794 .^{47}$

(c) The rural discourse of "serfs" equates "slavery" with serfdom, known especially from the debates on the (late) abolition of the designation "serf" at the end of the eighteenth century, such as in the Republic of Basel. ${ }^{48}$

\footnotetext{
46 Isaak Iselin (ed.), Ephemeriden der Menschheit, December 1776, pp. 34-36, "Freyheit". Citizens of the Republic can also determine that they are not "slaves" by the following facts: "No shameless citizen of the Republic who has flourished through me and my fellow Swiss citizens derides my judgement, [. . . ]. No merciless entrepreneur will take a kreutzer from me before I can provide my children with bread and sustenance, and nobody is allowed to demand a penny from me without any legal right, and he has to provide me with an invoice that we both consider accurate [. . . ]. I fear no order that, through abusing the name of our Lord and without indicating a reason, might force me to go where I do not want to go [. . .]." Compare Ulrich Im Hof, "Basel in Iselins Ephemeriden", Basler Zeitschrift filr Geschichte und Altertumskunde, 91 (1991), pp. 147-158.

47 Simon, Wollt lhr Euch der Sklaverei kein Ende machen?, pp. 25, 40, 68, 75-77, 83, $103,109$.

${ }^{48}$ Christian Simon, "Die Basler Landschaft und die franzősische Revolution. Aspekte des Verhältnisses zwischen Obrigkeit und Untertanen 1789-1797", Basler Zeitschrift für Geschichte und Altertumskunde, 82 (1982), pp. 65-96.
} 
- This context includes the struggle against the legal position of servants of entrepreneurs ${ }^{49}$ and the tendency to pose as manual guildsmen or journeymen and to demand appropriate treatment. Organizations of manufacture workers also used strategies specific to journeymen, such as denouncing factories where scabs worked or where the proprietors broke with custom. The honour code in manual trades helped these workers resist the intentions of their superiors to attribute the same status to the skilled workforce of manufactures as to servants or day labourers. The meeting and the conditions in which they took place, even the petition papers and addresses, had a symbolism beyond their verbal content as the expression of a claim to power or position by a specific professional group. Apparently, skilled manufacture workers used a specific discourse to aspire to the social positions occupied by manual craftsmen by dint of their "artisan ethos".so

- No Utopian excess is discernible beyond the observation of socioeconomic conditions and related opportunities (and dangers) as indicated. The analogous restriction of the journeymen's protest often resulted in talk of a guild-based mentality or immaturity and also caused walk-outs for similar reasons not to be labelled as strikes.

Freedom to choose employers, adequate wages, secure and exclusive access to certain jobs in the trade, honour based on their order and trade, self-esteem, and days off from work to celebrate festivities or when contributions sufficed (leisure provision): thus were the demands made by workers. The tradesmen also claimed control of the number of apprentices, the tasks that women and children were allowed to perform, and technical innovations. Workers perceived their situation in these terms.

There was no generic position known as "employee", but a social field of the trade and the company with a horizontal and a vertical structure. The actions often served to support a single group in this field, generally at the expense of another, less privileged one (women, apprentices).

\footnotetext{
49 For cases in Basel, see Simon, Wollt lhr Euch der Sklaverei kein Ende machen?, pp. 83, 97: "Printing and engraving are crafts that require study. Artisans in these crafts should therefore not be regarded as servants [. . . ]." In 1754, calico printing entrepreneur Rosenburger said that his workers should be considered Knecht und Mägd (servants and maids): Staatsarchiv Basel-Stadt, Protokolle O1, 1, p. 37 (10.7.1754). Even in the eighteenth century, honour did not result from work alone, but rather from art or skill, see Sewell, Work and Revolution, p. 23. Where powerful workers' organizations existed, they effectively defined workers' rights at the manufacturers.

${ }^{\text {so }}$ Sewell, Work and Revolution, p. 13.
} 


\section{ORGANIZATIONS AND GEOGRAPHIC MOBILITY}

The next question is whether migration affected the similarities between the printers' organizations and actions, as with the journeymen ${ }^{51}$ and whether interregional organizations were possible that embraced and upheld views on justice and claims to respect. The empirical findings deserve evaluation here.

For example, many places had funds for travel, illness and burial among printers, engravers and designers. These funds consisted of contributions from workers, sometimes administered solely by shop stewards (like the individuals at the manual journeymen's inns and shops, they were occasionally called Altgesellen), other times under the supervision of entrepreneurs. In conflicts, identical or parallel organizations could co-ordinate their operations, combine the protesters into a closed group and represent them before employers and authorities. Furthermore, at least with the English box clubs, money flowed smoothly from funds for illness to funds for strikes.

Nevertheless, there are at least two objections to identifying these fund administrating bodies as the manual trade associations of the corresponding organizations. One objection is that these funds could be established by the entrepreneurs to tie their staff to the company. The other problem is that the funds were available to local employees only. Only the records of the funds supervised by entrepreneurs and authorities are well known. There is good reason to believe that facilities established by workers in some positions were official, while others remained covert or secret. Changes of position during a dispute should not evoke astonishment. By the same token, publicly operated community offices might turn into cornerstones of resistance organizations in exceptional circumstances. ${ }^{32}$

s1 For migration of journeymen in the Reich (Walz), see Rainer S. Elkar, "Umrisse einer Geschichte der Gesellenwanderungen im Übergang von der Fruhen Neuzeit zur Neuzeit", in idem (ed.), Deutsches Handwerk in Spätmittelalter und fruher Neuzeit (Göttingen, 1983), pp. 85-116. For the Compagnonnage in France, see Luc Benoist, Le compagnonnage et les métiers (Paris, 1966), and Cynthia M. Truant, "Solidarity and Symbolism Among Journeymen: The Case of Compagnonnage", Comparative Studies in Society and History, 21 (1979), pp. 214-226.

s2 On friendly societies and funds administered by entrepreneurs, see for Peel in Bury, Chapman and Chassagne, Textile Printers, p. 56. In Basel, poor-relief funds were created by order of the city government in 1769 to serve migrant manufacture workers. These funds also provided allowances for journeymen who wanted to leave town after receiving an Abscheid form: Staatsarchiv Basel-Stadt, Protokolle 01,2, pp. 343 (4.12.1794), and Niederlassung A2, p. 76. A box administered by the confraternity of the calico printers is reported for Bern, see Werner Fetscherin, Beitrag zur Geschichte der Baumwollindustrie im alten Bern (Weinfelden, 1924), pp. 80ff. and Hedwig Schneider, Die bernische Industrieund Handelspolitik im 17. und 18. Jahrhundert (Zurich, 1937), p. 100. For Orange, see Chobaut, "Avignon et Orange", p. 151, and Chassagne, Naissance, p. 241. Also see Rule, Labouring Classes, p. 262; Dollfus-Ausset, Materiaux, p. 199; Chapman and Chassagne, Textile Printers, p. 122. 
In this respect, the journeys of the most skilled workers are significant, as well as the views gleaned from the lives of individuals who later became entrepreneurs. It certainly was an insignificant minority that met these special criteria. The course of their training, however, indicates how international the operations of a manufacturing industry such as textile printing were and how important the opportunity to acquire new skills by changing companies frequently. Accordingly, entrepreneurs feared this conduct as corporate espionage. ${ }^{53}$

Painstaking comparisons of lists of workers are required where less prominent individuals were concerned. For the French speaking part of France, some preliminary work by Serge Chassagne exists, although it has yet to appear in full. ${ }^{54}$ Jean-Marie Schmitt has gathered some interesting views on the Alsace premises which I would like to regard as confirmation of my thesis that colour mixers, designers, engravers and especially printers journeyed far and wide to acquire new knowledge and better wage and working conditions. ${ }^{3 s}$

Occasionally, traces of ties between local organizations appear, although it is very difficult to document them. It remains a hypothesis that at least the printers in cities (everywhere, in fact, where several companies existed in an area of settlement) established organizations

${ }^{33}$ Schulle's father was a nailsmith and the proprietor of an ironworks shop. He used to work the fairs with his son and one of the merchants Schulle met there hired his son as an apprentice. After this training, Schule became a merchant and later an entrepreneur with his own putting-out business (Verlag) and eventually proprietor of his world-famous calico printing manufacture in Augsburg; see Waizfelder, Schule, p. 68.

Oberkampf was the son of a German dyer who later became the proprietor of a small calico printing shop near Lenzburg. He moved with his father to Basel, from where he went to Lörrach alone, and later to Paris via Mulhouse. In Paris, Oberkampf's knowledge was important to a capitalist who founded a calico printing business at the moment this branch was legalized after a long ban, see Jean-Michel Tuchscherer, "La Manufacture Royale de Jouy-en-Josas", Bulletin de la Sociéte Industrielle de Mulhouse, 761, no. IV (1975), p. 22.

Jean Haussmann was from a family of physicians and chemists. He became the apprentice of a merchant, worked as a clerk for Schule, borrowed money from an Augsburg banker, and started his own calico printing business, see Schmitt, "Les établissements Haussmann", pp. 13-21.

J.-H. Dollfus was a painter who traded linen fabrics until he founded the first calico printing manufacture at Mulhouse with Schmalzer and Koechlin in 1746. His associates were capitalists from leading families of the town, see Jean-Michel Tuchscherer, "Les débuts de l'impression sur étoffes à Mulhouse", Bulletin Trimestriel de la Société Industrielle de Mulhouse, 761, no. IV (1975), pp. 17-20.

${ }^{34}$ Chassagne, Toumemine; idem, "Les ouvriers en indiennes de l'agglomération rouennaise 1760-1860", in Travail, metiers et professions en Normandie (Nogent-sur-Marne, 1984), pp. 125-139; Chassagne, La France d'Ancien Régime. Etudes réunies en l'honneur de Pierre Goubert, vol. I (Toulouse, 1984), pp. 119-128; Chassagne, Alain Dewerpe and Yves Gaulupeau, "Les ouvriers de la manufacture de toiles imprimées d'Oberkampf à Jouy-en-Josas 1760-1815", Le Mouvement Social, 97 (1976), pp. 39-88. In 1989, I was told he had accumulated all the necessary material, except for German-speaking Alsace.

ss Schmidt, Révolution industrielle. 
based on the patterns of trade guilds, which formed links as a result of the journeys of their members.

\section{CONCLUSION}

Conflicts resulted directly from labour conditions and from related trends of change. Discharge was an integral aspect of this relationship and a continuing source of conflict. Entrepreneurs had reason to get rid of unproductive workers, individuals whose work was poor, who incited the workforce to action, and who expected employment to continue during slow periods. On the other hand, there were long periods during which it was hard to find skilled workers in this industry. I am not referring to economic crisis, as occurred towards the end of the eighteenth century during the transition to closed national economies and the mechanization of printing. Consequently, entrepreneurs relied on their workers' whereabouts, their good conduct and their co-operation.

Other sources of disputes included changes that affected the circumstances prevailing in industrial relations. In times of prosperity, new companies arose, which could meet their immediate needs for manpower only by hiring workers away from other companies (débaucher). On the other hand, entrepreneurs repeatedly tried to make working conditions worse and to circumvent the obligations imposed upon them by organized labour. Their efforts could result in serious disputes. Conversely, another cause might be attempts by workers to tighten their control over the entrepreneurs.

Changes also included efforts to cut costs by hiring cheaper workers, especially women. One of the main purposes of printers' organizations often appears to have been excluding women from skilled positions. The position of women in early modern era society resulted in a relationship between women and men in the company, the industry, as well as in the field of production, that subordinated women because of their gender. Women in manufactures had a different status from men, and consequently they earned lower wages. While women's special status bothered the male workers, it worked in the favour - wherever the men tolerated it - of the entrepreneurs. Male journeymen seem to have succeeded in keeping women out of skilled tasks in the trade where small or medium companies existed in close proximity and the organizations managed to exercise control over the companies. Men were less successful in rural environments, where entrepreneurs not only provided short-term employment contracts to individuals, but tied entire families down for generations (fabrique au village). These specific conditions certainly merit further study.

Like women, children provided cheap labour, although child labour at printing workshops appears to have been restricted to the occurrence of teerers and pinceauteuses. An additional source of cheap labour, which 
served to cut costs and to fight the influence of organizations, consisted of apprentices. Organized skilled workers usually insisted that the ratio of qualified workers to apprentices should not deviate from a set figure. Their purpose was twofold: the apprentices were not to compete with the qualified workers as cheaper labour, and the ratio of supply and demand on the labour market should not change significantly. Further.more, the skilled workers made the years of apprenticeship so unpleasant that many apprentices had no choice but to break their contracts by leaving.

'Regarding these aims and methods, the skilled manufacture workers tended to behave like members of craft guilds, whereas the entrepreneurs had reason to employ women and children and to cultivate a large circle of successors in the field to create a free market for workers, which benefited the employers.

It is important to stress that relations inside manufactures rarely reflected direct confrontations between labour and.capital. Rather, they were usually mediated by various types of collectives. Entrepreneurs also used this practice, sometimes as individuals with private interests, other times as a coalition of employers.

The protection of their respective interests from internal and external forces required certain strategies of legitimation. They corresponded roughly to views typical of the ancien régime on law, justice, convention, custom and patriarchal duties. Nevertheless, there was no symmetry between duties and claims, as proprietors demanded complete authority over employees of the company. The staff, however, did not accept this demand beyond certain limits. The mention of "tyranny" indicated the limits of acceptable conduct.

In most of the cases for which documents remain, workers did not resist as individual suppliers of labour, but as members of organizations or groups. For this reason, conditions (hiring, working conditions, organization of the work, salary levels, etc.) by no means resulted from free market forces and bargaining between individual employers and employees, but developed according to the relationships (characterized by conflict and often by ritual) between these groups.

The authority of these group conditions, which extended beyond individual companies, depended on a company's success in evading them and in becoming a separate institution that regulated the lives of its "inmates". The variety in this industry was so large that it is impossible to generalize.

The issue of discipline was all-encompassing (while rural entrepreneurs seem to have suffered less from this problem, their responsibilities were greater because of the patriarchal aspect of care). This problem was exacerbated by differing interests (maximization of productivity and profits in view of the high share of wages in production costs or income optimalization as part of the subsistence issue) and the claim to freedoms as a sign 
of the dignity and honour of skilled workers (the emphatic disapproval of "slavery"). There was no conflict between interests and attitude in skilled workers' actions and discourses. Consequently, entrepreneurs wanted to tie skilled workers to the company during economic booms and tended to try to break agreements quickly when business was bad and to foster solidarity between proprietors to strip organized workers of their power, to control the labour market through a system of discharge slips and - if problems became acute - by involving the authorities. Of course, workers also used this tactic, which could stand them in good stead.

The social position of manufacture workers did not correspond to their self-image. Craftsmen, patricians, noblemen, administrators and authorities considered them day labourers, unskilled workers or servants to their bosses. By emphasizing their skills, requiring professional training and on the basis of their own organizations, which were based on trade guilds, they managed, by following the example of manual craftsmen from other trades, to carve out a precarious place for themselves which corresponded to their claims. That place was constantly questioned by other social groups and could only be defended if their industry flourished (i.e. until the 1780s). This society of orders did not provide alternative identities. The ascent to entrepreneur status or bourgeoisie was available only to selected individuals under certain conditions, and most likely to colour mixers, engravers and designers.

The downfall of the industry, which began in many countries towards the end of the eighteenth century, and the proletarianization that the trade experienced under pressure from the rise in job seekers, the reduction of skills required for mechanized mass production and decline of wages in certain regions, where the industry survived the crises of the Napoleonic wars, created a new, less favourable environment. The calico printers' trade turned into a factory industry, gentlemen journeymen were reduced to workers. The complex hierarchical organization featured in their trade faded from their discourse and made way for a perception of society that emphasized the conflict between the top and the bottom of this hierarchy. ${ }^{56}$

Translated by Lee Mitzman

s6 Prothero, Artisans and Politics, p. 332, emphasized the switch from the concept of orders to a discourse in terms of the unequal exchange between workers and merchants from 1820 to 1840 . 